\title{
SiM
}

\section{Agency Accomplishments: Making a Difference on the Ground}

\author{
By Linda Coates-Markle
}

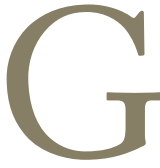

overnment land management agencies are not often provided adequate opportunities to market their successes because workloads and priorities often restrict time and budgets. At the request of an enlightened agency field employee-Ryan Martin, Rangeland Management Specialist, Dillon Field Office, Bureau of Land Management (BLM) - the BLM Liaison to the SRM organized a special session in concert with the 2011 SRM Annual Meeting and Trade Show to do just that. The session promoted opportunities for the agencies to demonstrate the often unique and well-fought efforts to accomplish laudable partner-based goals. The goal was to provide presentations that reflected the successes of agency partnerships with researchers and ranchers, nongovernmental organizations, and others. The presenters were encouraged to focus on projects that were ecoregional in nature and that demonstrated the variety of avenues to success. Presenters were asked to address the primary problem (the concern), discuss the collaborative process that brought the partners together, and highlight current accomplishments. The long-term intent of the session was to foster improved communication with the goal of developing more opportunities for successful partnerships and enhance management of the nation's natural resources.

The special session involved a full day of presentations at the 2011 SRM Annual Meeting in Billings, Montana. Twenty oral presentations ${ }^{i}$ were given, representing the collaborative efforts of researchers, field managers, forest supervisors, rangeland management specialists, range conservationists, landowners, ranchers, permittees, and others of the US Geological Service (USGS), Agricultural Research Service (ARS), Natural Resources Conservation Service (NRCS), US Forest Service (USFS), and the BLM with associated partners.

\footnotetext{
Abstracts of all the presentations in the 2011 Special Session "Agency Accomplishments-Making a Difference on the Ground" are available online at http://dx.doi.org/10.2111/RANGELANDS-D-12-00045.s1.
}

At the completion of the session, there was significant feedback from the audience that this information should be captured in a written format to help further convey the message about agency successes in working with partners and opportunities to make substantial on-the-ground differences in managing rangelands. The idea of a special issue of Rangelands was discussed as a viable venue, and of the original 20 presentations, 10 authors have further developed their oral presentations into peer-reviewed articles for inclusion in this special issue.

As the reader makes his or her way through these articles, it should become clear that a common theme in all these discussions is that partnerships take work but are, more often than not, worth it and are critical in setting the stage for future successes. Broader success in on-the-ground efforts is often more effectively and efficiently achieved by partners than it is by a single agency alone: the more complex the issue, the more value gained by reaching out to a broader array of diverse partners. Common goals are not always apparent at the beginning but do begin to develop as partners shape the road to success. Finally, success is often sweeter when shared.

Several of the articles relate success stories about the difficulties and rewards of integration of experimental research with site-specific practice. These stories range from the dayto-day on-the-ground interactions of scientists, managers, and agency advisors (weed management, land restoration, plant material development) to the compilation, analysis, and interpretation of national-level databases and models to assess the effectiveness of particular programs and practices. Other stories are about bringing multiple partners together at the landscape scale (riparian management, wildlife refuge management) to address conservation concerns by implementing proven technologies. Interestingly, successes can be found on private land (Texas Grazing Lands Conservation Initiative, Fort Worth, Texas), federal land (West Potrillos Grassland Restoration Project, BLM Las Cruces District Office, Las Cruces, New Mexico; Dillon Field Office, BLM, Dillon, Montana), and mixed ownership (Rawlins Field Office, BLM, Rawlins, Wyoming). Collectively, these stories 
demonstrate that successful rangeland management has no specific recipe but many common elements, including technical expertise, commitment, trust, and, probably most important, a desire to make it work.

The organizers extend their thanks to the many individuals who gave of their time and expertise to pull these success stories together, both for the special session in Billings and for this special issue of Rangelands. Additional thanks to those who volunteered to moderate the session: Rob Roudabush, Chief, Division of Rangeland Resources, BLM (retired); Janette Kaiser, Director for Rangelands, USFS (retired); and Dennis Thompson, Range and Grazing Land Ecologist, NRCS. Our collective appreciation is extended to Lori Hidinger (Rangelands Editor-in-Chief) and Joel
Brown (Guest Editor), who made themselves available to assist authors with their conversion of oral presentations to written articles worthy of publication and to the reviewers who suggested ways to strengthen each article. A very special thank you to the cosponsors of this issue: the Division of Rangeland Resources, ii Bureau of Land Management, Washington, DC, and the Agricultural Research Service, Reno, Nevada, whose contributions have made this special issue a reality.

Author is Wenatchee Field Manager, Bureau of Land Management, 915 Walla Walla Avenue, Wenatchee, WA 98801, USA, and former BLM-SMR Liaison, lcmarkle@blm.gov. 